\title{
Soil dehydrogenase in a land degradation-rehabilitation gradient: observations from a savanna site with a wet/dry seasonal cycle
}

\author{
Ryoichi Doi \& Senaratne Leelananda Ranamukhaarachchi \\ AFE Building, Asian Institute of Technology, Klong Luang, Pathumthani 12120, Thailand; \\ roird@aeiou.pt; frtbmb@hotmail.com
}

Received 22-IX-2007. C Corrected 20-IX-2008. Accepted 23-X-2008.

\begin{abstract}
Soil dehydrogenase activity is a good indicator of overall microbial activity in soil, and it can serve as a good indicator of soil condition. However, seasonal changes in soil moisture content may have an effect on soil dehydrogenase activity, making an accurate assessment of soil condition difficult. In this study, we attempted to determine the significance of soil dehydrogenase activity for assessing soil condition, and we attempted to find a way to account for the influence of soil moisture content on soil dehydrogenase activity. Soils were sampled in dry evergreen forest (original vegetation), bare ground (severely degraded) and Acacia plantation plots established on bare ground in 1986 and 1987 in Sakaerat, Thailand. Soil physico-chemical characteristics and dehydrogenase activity in the Acacia plantation soil had few differences from those in the evergreen forest soil. Soil dehydrogenase activity varied significantly between the bare ground and the forests regardless of the season (wet or dry), while the season did not produce a significant variation in soil dehydrogenase activity, as determined by repeated measures analysis of variance $(\mathrm{p}=0.077)$. The physico-chemical data provided the first principal component as a good measure of soil fertility. Values of soil dehydrogenase activity significantly correlated to scores of the soil samples of the first principal component $(\mathrm{R}=0.787, \mathrm{p}<0.001)$. We found that soil dehydrogenase activity is a useful indicator of the extent of soil degradation and the rehabilitative effects of reforestation in this part of Thailand. Rev. Biol. Trop. 57 (1-2): 223-234. Epub 2009 June 30.
\end{abstract}

Key words: Acacia auriculiformis, land degradation and rehabilitation, savanna, soil dehydrogenase, soil moisture.

Soil microbes contribute to plant growth in various ways (Albrecht et al. 1981, Handman et al. 1991, Derylo and Skorupska 1992), and soil dehydrogenase activity is an indicator of soil microbial activity (Herman and Maier 2000). Soil dehydrogenase activity responds to changes in soil quality related to previous land usage (Rao et al. 2003) and other factors such as soil pollution with heavy metals (Hinojosa et al. 2004) or herbicides (Wingfield et al. 1977). Soil dehydrogenase activity reflects the workings of a group of intracellular enzymes that are present in living soil microbes. These enzymes take part in many metabolic reactions involved in oxidative energy transfer (Smith et al. 1983). Since dehydrogenases are not active as extracellular enzymes in soil, soil dehydrogenase activity is considered to be a good indicator of overall microbial activity (Dick 1997).

In addition to land degradation, soil dehydrogenase activity may be affected by changing season, in particular, a wet/dry seasonal cycle. In a savanna region, soil dehydrogenase activity reflected seasonal changes in soil moisture (López-Gutiérrez et al. 2004). When a soil sample is air-dried, the dehydrogenase activity may increase (Rao et al. 2003) or decrease (Ross and McNeilly 1972, Rao et al. 2003) depending on the makeup of the soil itself or the particular soil horizon. These past findings led us to consider wet/dry seasonal changes 
when soil dehydrogenase activity is used as an indicator of the intensity of land degradation.

In this study, we analyzed changes in soil dehydrogenase activity to test the hypothesis that this activity is affected by land degradation/rehabilitation (soil condition) and wet/ dry seasonal moisture changes. The Sakaerat Environmental Research Station, Thailand, has a land degradation-rehabilitation gradient (Doi and Sakurai 2004), and the area undergoes an annual wet/dry seasonal cycle (Bunyavejchewin 1986). In the dry season, the soil becomes drier, and it was expected that this would affect the levels of dehydrogenase activity for soils across the entire land degradation-rehabilitation gradient. The objective of this study was to test the following hypothesis: soil dehydrogenase activity in Sakaerat changes significantly between the wet and dry seasons, and this seasonal variation is more pronounced than the variation along the land degradation-rehabilitation gradient. The relative significance of the soil moisture changes was analyzed by multiple regression analyses assuming abiotic soil environmental gradients (McCune et al. 2002) as the predictors of soil dehydrogenase activity.

\section{MATERIALS AND METHODS}

Site description: The Sakaerat Environmental Research Station, Wang Nam Kiao district, Nakhon Ratchasima (14³0' N, $101^{\circ} 55^{\prime}$ E) was established in 1967. At that time, most of the area had already been disturbed by human activities (Kaeoniam et al. 1976). The area is 7808 hectares and the altitude ranges from 250 to $762 \mathrm{~m}$ above mean sea level. The climate is classified as savanna (Köppen 1931). The area includes dry evergreen forest, dry deciduous forest and plantation plots as the major vegetative types (Fig. 1). The vegetative types are distributed in a mosaic pattern in the northeastern part of the site. Bare ground, having no vegetation as a result of past human activities, is also scattered in the mosaic. The soil is originally an Orthic Acrisol, according to the FAO/UNESCO scheme (FAO/ UNESCO 1979).

In this work, dry evergreen forest, Acacia plantation and bare ground soils were compared. The vegetative types were randomly distributed. Thus, the vegetative mosaic was regarded as a completely randomized design (Doi and Sakurai 2004). The numbers of repli-

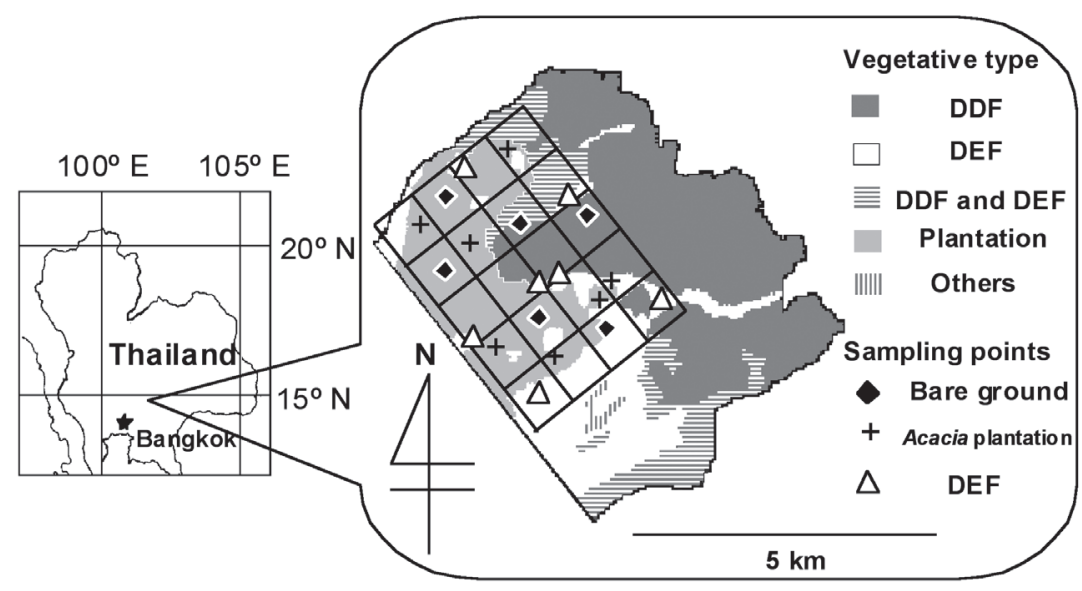

Fig. 1. Map the Sakaerat Environmental Research Station (SERS) and the sampling points. DDF and DEF indicate dry deciduous forest and dry evergreen forest, respectively. 
cations were 7, 7 and 6 for dry evergreen forest, Acacia plantation and bare ground, respectively. All the sampling points were on slight slopes (less than $10^{\circ}$ ).

The dry evergreen forest is primarily dominated by Hopea ferrea and Shorea spp. that form the upper storey 20 to $40 \mathrm{~m}$ above ground. A typical dry evergreen forest fosters more than 1000 trees (trunk diameter at breast height $>5 \mathrm{~cm}$ ) $\mathrm{ha}^{-1}$, the total basal area at $1.3 \mathrm{~m}$ height exceeds $30 \mathrm{~m}^{2} \mathrm{ha}^{-1}$ and the above ground biomass is over 200 tons $^{-1} \mathrm{a}^{-1}$ (Kanzaki et al. 1995).

The Acacia auriculiformis plantation plots are scattered in the area (Fig. 1). The Acacia plots were established in 1986 and 1987 in the areas that were subjected to slash and burn shifting cultivation (Kaeonium et al. 1976). In this area, the original vegetation had been removed and the biomass had been burnt. The cleared area had been cultivated for a few years, and then abandoned when the soil quality deteriorated to the extent that could not support crop production. Some of the abandoned areas had been converted to plantation plots of Acacia mangium, Eucalyptus camaldulensis and other tree species. A. auriculiformis was one of the introduced tree species.

The bare ground soil has been intensively deprived of nutrients and has lost conditions seen in forest soils. At these sampling points, restoration of vegetative cover did not occur and the harsh conditions for plants make the bare ground remain so. Morphological features of bare ground can still be seen at some points in the site. For typical bare ground, the A horizon can not be recognized. The uppermost horizon is reddish brown, rich in gravel, and has few roots and other plant organs/debris. The boundary between the uppermost horizon and the deeper horizon is not clear, while the horizon deeper than $50 \mathrm{~cm}$ is pale orange (Doi and Ranamukhaarachchi 2007b).

Soil sampling: To investigate effects of the wet/dry seasonal cycle, soils were sampled on Sep 25 and 26, Nov 25 and 26, Dec 24 and 25, 2005 and Feb 27 and 28, 2006 (Fig. 2). The sampling was done within 26 hours, in which the area had negligible precipitation $(<1 \mathrm{~mm})$. At each sampling point, hundred-mL core samplers, $5 \mathrm{~cm}$ in diameter, were inserted from the surface to a depth of $5.1 \mathrm{~cm}$. A circle, 10 $\mathrm{m}$ in diameter was established, and eight soil cores were randomly taken within the circle. In addition, two other cores were randomly taken in the circle for soil moisture and bulk density measurements. The eight soil cores were immediately placed into a single plastic bag, mixed and brought to the laboratory. For measuring soil dehydrogenase activity, the moist soil immediately passed through $2 \mathrm{~mm}$ sieve and was used for the assay. For soil physico-chemical analyses, the soil samples were air-dried, passed through $2 \mathrm{~mm}$ sieve then analyzed.

Physico-chemical analyses of soils: The following methods were applied as previously reported (Doi and Sakurai 2004). Soil moisture content and bulk density were determined using oven drying at $105^{\circ} \mathrm{C}$ for $48 \mathrm{~h}$. The airdried and sieved soil was suspended in water at a soil to solution ratio of 1:5 and reciprocally shaken at room temperature for $1 \mathrm{~h}$ at $120 \mathrm{rpm}$ to determine its $\mathrm{pH}$. Soil organic matter was determined by the loss of ignition method. Exchangeable cations ( $\mathrm{Ca}, \mathrm{K}, \mathrm{Mg}$ and $\mathrm{Na}$ ) were extracted with $1 \mathrm{M}$ ammonium acetate $(\mathrm{pH}$ 7.0), then $\mathrm{Ca}, \mathrm{K}$ and $\mathrm{Na}$ were determined with an atomic absorption spectrophotometer. The sum of $\mathrm{Ca}$ and $\mathrm{Mg}$ contents in the extract was determined with the eriochrome black titration method, then the $\mathrm{Ca}$ content was subtracted from the sum to determine the $\mathrm{Mg}$ content. Exchangeable acidity ( $\mathrm{Al}$ and $\mathrm{H}$ ) was determined with titration. Available phosphorus was determined by the Bray II method. Cation exchange capacity was calculated as the sum of the four exchangeable cations $(\mathrm{Ca}, \mathrm{K}, \mathrm{Na}$ and $\mathrm{Mg}$ ) and the exchangeable acidity. Soil fertility index (Moran et al. 2000) and soil evaluation factor (Lu et al. 2002) were calculated to quantify the intensity of land degradation in the study site (Doi and Sakurai 2004). The following equations were used to calculate integrative soil quality indices: 

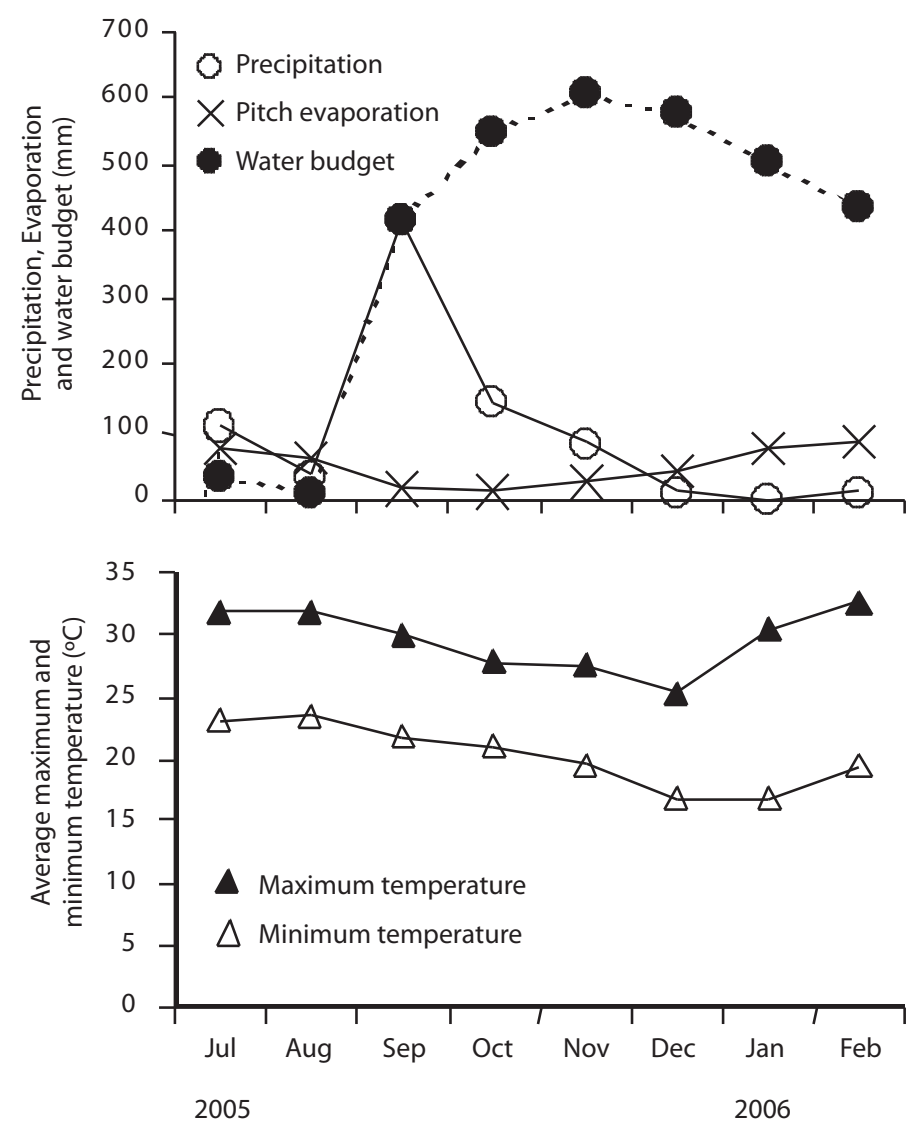

Fig. 2. Meteorological data during the research period.

Soil fertility index $=\mathrm{pH}+$ organic matter $(\%$, dry soil basis) + available $\mathrm{P}(\mathrm{mg} / \mathrm{kg}$ dry soil $)+$ exch K (c eq/kg dry soil) + exch Ca (c eq $/ \mathrm{kg}$ dry soil) + exch Mg (c eq/kg dry soil) - exch $\mathrm{Al}$ (c eq/kg dry soil)

Soil evaluation factor $=[$ Exch $\mathrm{K}(\mathrm{c}$ eq $/ \mathrm{kg}$ dry soil) + exch $\mathrm{Ca}$ (c eq/kg dry soil) + exch Mg (c eq/kg dry soil $)-\log (1+$ exch $\mathrm{Al}(\mathrm{c}$ eq $/ \mathrm{kg}$ dry soil))] X organic matter (\%, dry soil) +5

Soil dehydrogenase activity measurement: Soil dehydrogenase activity was measured within $12 \mathrm{~h}$ after sampling the last sample. The activity was determined by colorimetric measurement of the reduction of 2, 3, 5-triphenyltetrazolium chloride to triphenyltetrazolium formazan according to the method of Casida et al. (1964). Five grams of fresh soil were suspended in $5 \mathrm{~mL}$ of $250 \mathrm{mM}$ tris- $\mathrm{HCl}$ buffer ( $\mathrm{pH}$ 7.4) containing $3.47 \mathrm{mM}$ glucose. The enzymatic reaction started when 1 $\mathrm{mL}$ of $2.5 \%(\mathrm{w} / \mathrm{v})$ triphenyltetrazolium chloride solution was added to the soil suspension. The reaction took $12 \mathrm{~h}$ in the dark at $37^{\circ} \mathrm{C}$, mixing the suspension occasionally. The reaction was stopped by adding methanol. The methanol suspension was passed through cotton plug, filled up to $100 \mathrm{~mL}$ with methanol, and the formazan was measured colorimetrically at 480 $\mathrm{nm}$. The control was prepared by mixing the soil sample with methanol before adding the tris- $\mathrm{HCl}$ buffer and the tetrazolium solution. The coloration for the control was a negligible 
value of less than $3 \%$ of the sample value, suggesting the negligible abiotic formation of the formazan (Wada et al. 1978).

Effects of air-drying, re-moistening and $5{ }^{\circ} \mathrm{C}$ refrigeration of soil on soil dehydrogenase activity: In the above conditions, soil dehydrogenase activity was not significantly affected by the seasonal cycle. This was unexpected, and therefore, the November samples were air-dried to confirm if the soils' dehydrogenase activity significantly respond to more intensive drying that intensively deprives the microbial niche of moisture. The air-dried soil samples were also re-moistened to examine if the re-moistening treatment restores the original dehydrogenase activity (Hinojosa et al. 2004). The air-drying treatment took 30 days at $26^{\circ} \mathrm{C}$ in the dark and the air-dried soil was kept in a plastic bag. The residual soil moisture was determined using oven drying at $105{ }^{\circ} \mathrm{C}$ for $48 \mathrm{~h}$. After the air-drying treatment, the soil moisture contents were; bare ground, $1.57 \%$ \pm 2.86 ; Acacia plantation, $2.09 \% \pm 1.34$; evergreen forest, $2.07 \% \pm 1.94$. In the re-moistening treatment, distilled and sterilized water was supplied to the air-dried soil sample to give the field moisture content, previously determined by oven drying at $105^{\circ} \mathrm{C}$. The re-moistened soil sample was incubated at $26{ }^{\circ} \mathrm{C}$ in the dark for another month in a tightly closed plastic bottle. The bottle was occasionally ventilated by opening the cap.

This confirmatory experiment was extended to investigate whether the widely adopted soil storage method at $5{ }^{\circ} \mathrm{C}$ significantly affects soil dehydrogenase activity. The December soil samples were used for this experiment. The soil in a plastic bag was stored in a refrigerator immediately after the sampling and sieving. The soil was kept for 12 and 25 days before the dehydrogenase activity was measured.

Data analyses: All the following analyses were performed using the statistical software, SPSS 10.0.1 (SPSS Inc.). Repeated measures analysis of variance for each of the soil physicochemical characteristics and soil dehydrogenase activity was performed. Dunnett T3 t-test was performed to examine the significant differences between means. Principal component analysis of the soil physico-chemical data was performed to extract a principal component for describing the land degradation-rehabilitation gradient. Linear regression analysis was performed to examine a linear relationship between values of soil dehydrogenase activity and scores on the principal component for describing the degradation-rehabilitation gradient. Multiple regression analysis was performed to determine abiotic soil environmental factors that were significantly correlated to soil dehydrogenase activity. In the multiple regression analysis, the stepwise method at the default criteria ( $\mathrm{p}=0.05$ for inclusion and 0.10 for removal) was chosen.

\section{RESULTS}

Physico-chemical soil characteristics and soil dehydrogenase activity: There was a significant correlation between the land degradation/rehabilitation and most soil variables that we tested $(p<0.05$, Table 1$)$. Soil from degraded land showed high values for bulk density and exchangeable $\mathrm{Al}$ content, and low values for moisture content, $\mathrm{pH}$, organic matter content, contents of basic cations $(\mathrm{K}, \mathrm{Ca}, \mathrm{Mg})$ and available phosphorus. In most comparisons, the values for the Acacia plantation soil were not significantly different from those for the evergreen forest soil. For several soil characteristics, the bare ground soil was significantly poorer than that from the evergreen forest or the Acacia plantation. The Acacia plantation soil showed the restorative effects of the plantation on the degraded soil. The wet to dry season transition produced significant changes in soil moisture content, bulk density and $\mathrm{pH}$. However, there was not a significant change in soil dehydrogenase activity between the wet and dry seasons. There was, however, a significant difference in soil dehydrogenase activity between the bare ground and the forests. Thus, our hypothesis that seasonal variations in soil moisture content have more influence than the 


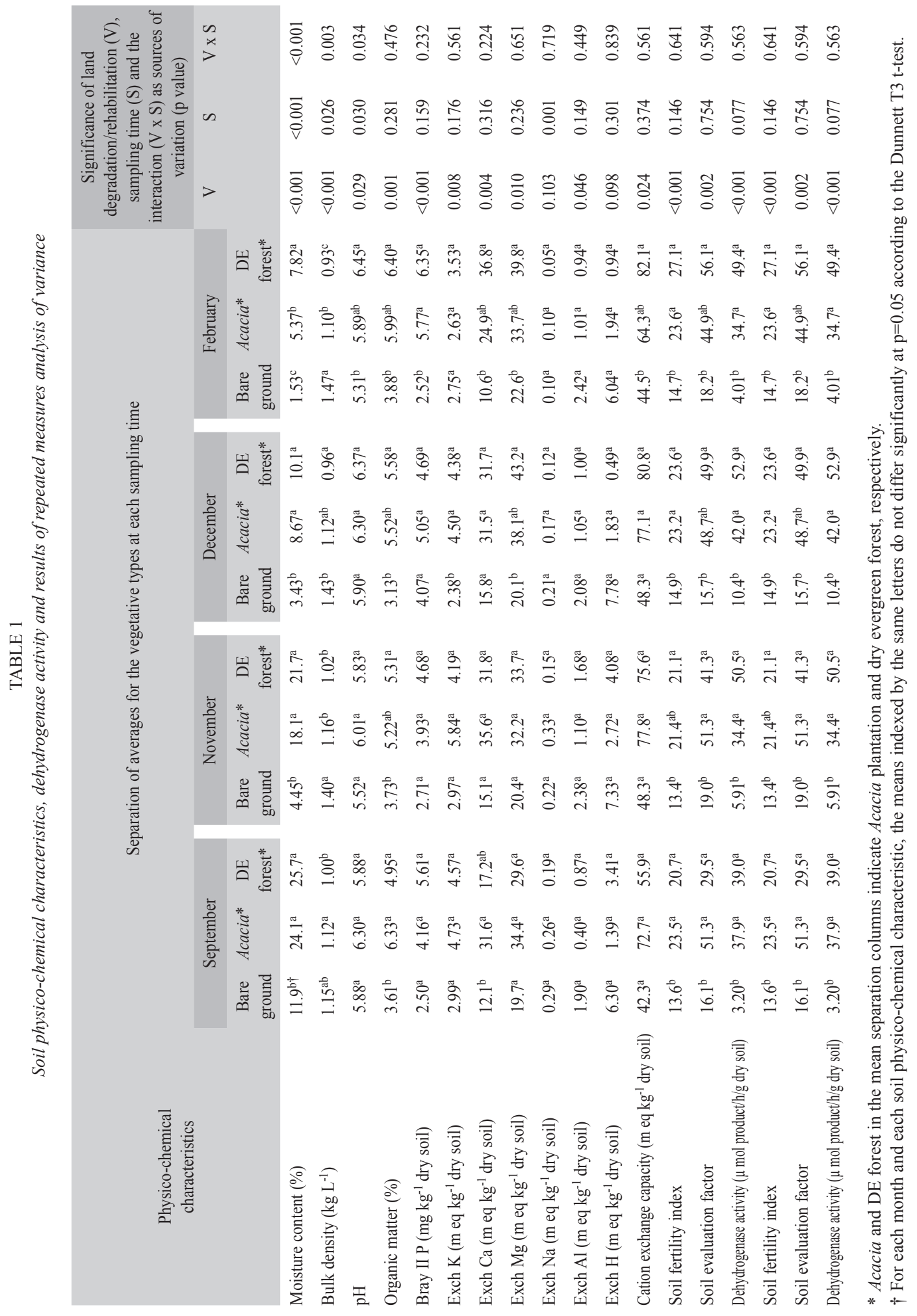


land degradation/rehabilitation on soil dehydrogenase activity was not borne out.

Relationship between the physico-chemical soil variation and soil dehydrogenase activity: The physico-chemical data for the soil samples we tested are shown in Table 2. According to Kaiser's criterion (Kaiser 1960), the first four principal components were significant, and these four principal components explained $78 \%$ of the total variation, reflecting its simple data structure. The first principal component accounted for a large part of the total variation as described in a previous report about soils in Sakaerat (Doi and Sakurai 2004). For the characteristics that favor plant growth, the values of eigenvectors on the first principal component were positive, while those for bulk density and exchangeable acidity were negative. An analysis of variance for the first principal component showed that degradation/rehabilitation was a significant source of variation $(\mathrm{p}<0.001)$, while sampling time and the interaction were not significant $(\mathrm{p}>0.502)$. Hence, as shown in a previous report (Doi and Sakurai 2004), the first principal component axis is the general soil fertility indicator. The relationship between the first principal component scores and the values of dehydrogenase activity was liner $(\mathrm{R}=0.787, \mathrm{p}<0.001)$. Therefore, the variation of soil dehydrogenase activity reflected the land degradation/rehabilitation significantly.

Effects of air-drying soil and refrigeration on soil dehydrogenase activity: Air-drying and the re-moistening treatments resulted in no significant differences in soil dehydrogenase

TABLE 2

Results of principal component analysis of the physico-chemical data

\begin{tabular}{lcccccc} 
Statistic & \multicolumn{5}{c}{ Principal components } \\
Eigenvalue & 1 & 2 & 3 & $\underline{1.32}$ & $\underline{1.16}$ & 0.62 \\
Variation explained (\%) & $\underline{5.08^{\dagger}}$ & $\underline{1.83}$ & 11.0 & 9.69 & 5.17 & 83.5
\end{tabular}

\begin{tabular}{lccccc} 
Physico-chemical characteristic & \multicolumn{5}{c}{ Eigenvectors } \\
Moisture & 0.31 & 0.19 & 0.65 & -0.52 & -0.23 \\
Bulk density & -0.50 & 0.19 & -0.69 & -0.10 & 0.03 \\
Organic matter & 0.78 & 0.20 & 0.19 & 0.29 & 0.03 \\
pH & 0.72 & -0.41 & -0.25 & -0.05 & -0.19 \\
Bray II P & 0.25 & -0.69 & 0.30 & 0.02 & 0.58 \\
Exchangeable Na & 0.33 & 0.55 & -0.22 & -0.54 & 0.35 \\
Exchangeable Ca & 0.94 & 0.07 & -0.17 & 0.09 & 0.06 \\
Exchangeable K & 0.75 & 0.32 & -0.12 & -0.22 & -0.13 \\
Exchangeable Mg & 0.91 & 0.07 & -0.06 & 0.27 & 0.17 \\
Exchangeable Al & -0.44 & 0.47 & 0.09 & 0.56 & 0.06 \\
Exchangeable H & -0.40 & 0.61 & 0.36 & 0.11 & 0.10 \\
Cation exchange capacity & 0.91 & 0.28 & -0.05 & 0.24 & \\
* Cumulative \% of the variation of multivariate profile explained by the primary principal components & \\
$\dagger$ \\
1, Keiser 1960).
\end{tabular}


activity among the soils (Fig. 3). Land degradation/rehabilitation and air-drying/re-moistening together were significant ( $p<0.001$ for both) as sources of the variation, while their interaction was not significant $(\mathrm{p}=0.104)$. This lack of significance can be attributed to decreases in the original dehydrogenase activity in the forest soils. Re-moistening treatment did not restore the original activity.

Refrigeration at $5{ }^{\circ} \mathrm{C}$ was also a significant source of variation in soil dehydrogenase activity $(\mathrm{p}=0.008)$, but it was less significant than air-drying/re-moistening $(\mathrm{p}<0.001)$. Land degradation/rehabilitation was more significant $(p<0.001)$ as a source of variation than refrigeration at $5^{\circ} \mathrm{C}$, while their interaction was not significant $(\mathrm{p}=0.219)$, and the differences in dehydrogenase activity between the bare ground soil and the forest soils continued even in the conditions of refrigeration.

Multiple regression models: Multiple regression analyses showed that exchangeable $\mathrm{Mg}$ content was the most significant soil characteristic, and it accounted for $63 \%$ of the total variation in soil dehydrogenase activity (Table $3)$. Soil moisture content was the third most significant, following Bray II P content, which accounted for only a small part $(4.3 \%)$ of the variation in soil dehydrogenase activity.

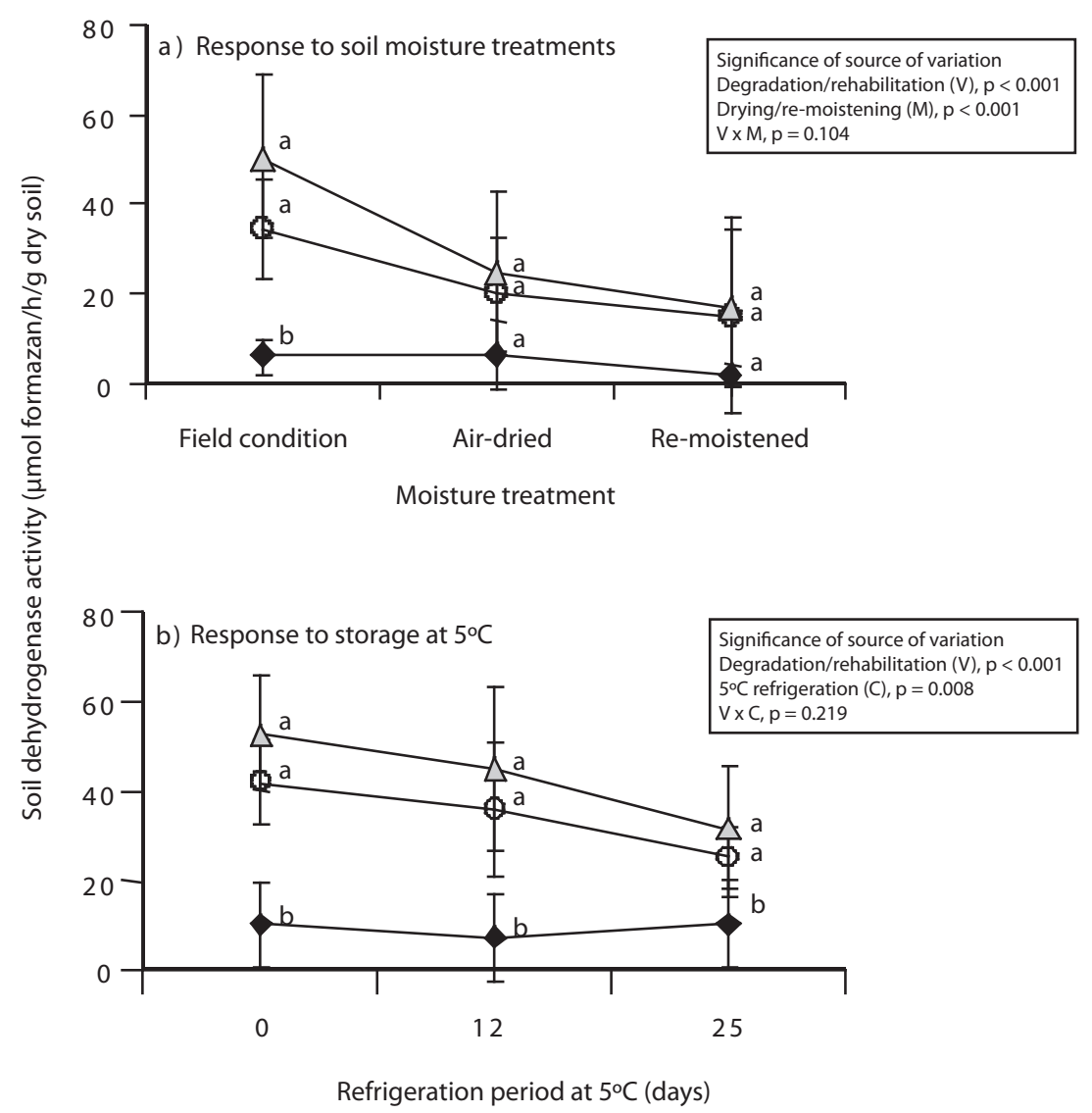

Fig. 3. Effects of soil moisture treatment (a) and $5^{\circ} \mathrm{C}$ refrigeration (b) on soil dehydrogenase activity. The diamond, open circle, and triangle indicate bare ground, Acacia plantation and dry evergreen forest, respectively. The values indexed by the same letter for each moisture treatment and storage period do not have significant differences at $\mathrm{p}=0.05$ according to the t-test. 
TABLE 3

Multiple regression models for describing variation of soil dehydrogenase activity in Sakaerat

\begin{tabular}{cccl}
\multirow{2}{*}{ Model } & \multicolumn{2}{c}{ Model fitness } & Dehydrogenase activity $(\mu$ mol formazan $/ \mathrm{h} / \mathrm{g}$ dry soil $)=$; \\
\cline { 2 - 4 } & $\mathrm{R}$ & $\mathrm{p}$ & \\
1 & 0.630 & $<0.001$ & Exch $\mathrm{Mg}(\mathrm{m} \mathrm{eq} / \mathrm{kg}$ dry soil $) \times 0.957+1.81$ \\
2 & 0.747 & $<0.001$ & Exch $\mathrm{Mg}(\mathrm{m} \mathrm{eq} / \mathrm{kg}$ dry soil $) \times 0.890+$ Bray II P $(\mathrm{mg} / \mathrm{kg}$ dry soil $) \times 4.36-15.3$ \\
3 & 0.790 & $<0.001$ & $\begin{array}{l}\text { Exch } \mathrm{Mg}(\mathrm{m} \mathrm{eq} / \mathrm{kg} \text { dry soil }) \times 0.830+\text { Bray II P }(\mathrm{mg} / \mathrm{kg} \text { dry soil }) \times 4.28-\text { Moisture } \\
(\%) \times 0.642-21.0\end{array}$
\end{tabular}

\section{DISCUSSION}

Significance of exchangeable soil $\mathrm{Mg}$ content: In some cases, variation of soil enzymatic activity among soils in question was significantly attributable to differences in soil organic matter content (Gianfreda and Bollag 1996, Baligar et al. 1999). Baligar et al. (1991) found exchangeable $\mathrm{Mg}$ content to be a significant abiotic determinant of soil dehydrogenase activity.

The reduction of the tetrazolium compound could be enhanced by exchangeable $\mathrm{Mg}$ in the dehydrogenase reaction mixture. A preliminary comparison between the evergreen forest and the bare ground soils showed that the oxidation rate of the tetrazolium compound of the Biolog EcoPlate (on which effects of available soil nutrients were minimized) was twice as high in the evergreen forest soil as in the bare ground soil (Doi 2005). On the other hand, in the current assay conditions, the dehydrogenase activity was five to ten times higher in the evergreen forest soil than in the bare ground soil (Table 1). The increased difference in the present study may be due to the contribution of exchangeable $\mathrm{Mg}$ in the reaction mixture as the cofactor (Karr and Emerich 2000).

Protective effects of soil structure on microbial survival: Decreases in dehydrogenase activity in air-dried forest soils suggest a protective function of soil pores (Chenu and Stotzky 2002). Soil microbial cells tend to gather in the spaces where their protective effects help their survival (Heijnen et al. 1993).
In these pores, soil moisture is relatively well retained, while it dries easily in other soil spaces (Adl 2003). Furthermore, it has been found that soil moisture distributes unevenly (Ehlers et al. 1995). If soil is sieved and air-dried by spreading the soil and occasionally mixing on a plate, fragile spaces are broken and lose their moisture rapidly. When there is a rapid decrease in moisture due to air-drying, some microbes may actually die (Paul and Clark 1989). To restore the original soil microbial activity in the forest soils, it would be necessary to restore the lost fragile spaces broken by the air-drying treatment (Leij et al. 2002). Thus, it appears that remoistening alone was ineffective in restoring the dehydrogenase activity because of the loss of soil structure and moisture.

The relatively minor decreases in soil dehydrogenase activity that were caused by refrigeration at $5{ }^{\circ} \mathrm{C}$ suggest that the retention of the soil moisture protected the microbes. Dehydrogenase activity in a temperate forest soil showed a significant increase after a comparable storage period of 29 days at $4{ }^{\circ} \mathrm{C}$ (Ross and McNeilly 1972). The decreases in activity due to refrigeration that we observed (Fig. 3) may be due to the fact that the microbes in tropical soil are unable to withstand cold temperatures.

Air-drying of soil samples is used when it is difficult to assay soil enzymatic activity immediately after the sampling (Gianfreda and Bollag 1996), and it has been found that $\beta$-glucosidase activity in an alluvial sandy soil did not change after air-drying (Rao et al. 2003). However, in some cases, air-drying of soil significantly 
affects the enzymatic activity. Dehydrogenases do not show enzymatic activity if the microbial cells are dead, and this happens when a soil sample is air-dried (Paul and Clark 1989). We believe that there was still sufficient moisture in the soil in February (the driest month in Sakaerat, Thailand) to protect the soil microbes. However, it is expected that some microbes may die when this soil is air-dried.

Rehabilitative effects of reforestation on soil microbial activity: Comparisons between the Acacia plantation soil and the other soils show the restorative effects of Acacia planting (Doi and Ranamukhaarachchi 2007a, Table 1). The microbial function has also been restored, as shown by the fact that there were no significant differences in soil dehydrogenase activity between the Acacia plantation and the evergreen forest soils. The Acacia trees had been growing for 18 or 19 years, during which time many native species have returned to the plantation plots (Kamo et al. 2002). Thus, planting of $A$. auriculiformis and the return of native species may restore the original soil microbial activity. Increasing the diversity of plant community can help enrich soil fertility (El-Keblawy and Ksiksi 2005) and establish the soil's ecological structure (Beare et al. 1995). In an adjacent paddy field, the soil fertility, expressed as a soil fertility index (Moran et al. 2000), was comparable to the bare ground soil, and the value of dehydrogenase activity was poor $(1.81 \pm 0.74 \mu \mathrm{mol}$ formazan $/ \mathrm{h} / \mathrm{g}$ dry soil $[n=40])$. This shows the difficulty of restoring microbial activity when the land is burdened with agricultural production.

Soil dehydrogenase as a single measure of land degradation and rehabilitation: $I n$ this study, changes in soil dehydrogenase activity correlated very well with the land degradation/ rehabilitation. The dehydrogenase assay offers a continuous measure of soil microbial activity as a result of the total redox sequences (Smith et al. 1983). Moreover, various soil microbes have redox sequences in their cells. The dehydrogenase assay is superior to techniques that involve threshold-manner observation such as most-probable-number counting of a target soil microbial group (e.g., Soares et al. 2006). These techniques may be unsuitable for describing a gradient that significantly correlates to the activity of microbial cells, in which these cells are more or less active depending upon environmental condition, but do not actually die in the environment.

Thus, it appears that the assay of soil dehydrogenase activity can serve as an integrative measure of soil quality. A soil ecosystem includes many microbes that can reduce tetrazolium compounds (Sollod et al. 1992) Dehydrogenase isozymes of a microbial species respond to different environmental impacts in different ways (Berchet et al. 2000), while the formation of formazan can be measured as a single variable. This value has a highly significant correlation with the first principal component, suggesting its integrative nature; i.e., formazan formation represents various redox reactions. This study shows that soil dehydrogenase activity is a useful single criterion for measuring the status of land degradation and the rehabilitation in the field. This technique will minimize labor, expense and time spent for monitoring soil quality in land rehabilitation efforts in savanna regions.

\section{ACKNOWLEDGMENTS}

All the staff members of the Sakaerat Environmental Research Station assisted this activity. We gratefully acknowledge the support from these people.

\section{REFERENCES}

Adl, S.M. 2003. The ecology of soil decomposition. CAB International, Wallingford, UK.

Albrecht, S.L., Y. Okon, J. Lonnquist \& R.H. Burton. 1981. Nitrogen fixation by corn-Azospirillum association in a temperate climate. Crop Sci. 21: 301-306.

Baligar, V.C., R.J. Wright, N.K. Fageria \& G.V.E. Pitta. 1999. Enzyme activities in cerrado soils of Brazil. Commun. Soil Sci. Plant Anal. 30: 1551-1560. 
Baligar, V.C., R.J. Wright \& M.D. Smedley. 1991. Enzyme activities in Appalachian soils: 4. Dehydrogenase. Commun. Soil Sci. Plant Anal. 22: 1797-1804.

Beare, M.H., D.C. Coleman, D.A. Crossley Jr., P.F. Hendrix \& E.P. Odum. 1995. A hierarchical approach to evaluating the significance of soil biodivesity to biogeochemical cycling. Plant Soil 170: 5-22.

Berchet, V., D. Boulanger \& A.M. Gounot. 2000. Use of gel electrophoresis for the study of enzymatic activities of cold-adapted bacteria. J. Microbiol. Meth. 40: 105-110.

Bunyavejchewin, S. 1986. Ecological studies of tropical semi-evergreen rain forest at Sakaerat, Nakhon Ratchasima, northeast Thailand, I vegetation patterns. Nat. Hist. B. Siam Soc. 34: 35-57.

Casida Jr, L.E., D.A. Klein \& T. Santoro. 1964. Soil dehydrogenase activity. Soil Sci. 98: 371-376.

Chenu, C. \& G. Stotzky. 2002. Interactions between microorganisms and soil particles: an overview, p. 3-40. In P.M. Huang, J.M. Bollag \& N. Sensi (eds.). Interactions between soil particles and microorganisms and the impact on the terrestrial ecosystem. Jhon Wiley \& Sons, Ltd., West Sussex, United Kingdom.

Derylo, M. \& A. Skorupska. 1992. Rhizobial siderophore as an iron source for clover. Physiol. Plant. 85: 549553.

Dick, R.P. 1997. Enzyme activities as integrative indicators of soil health, p. 121-156. In C.E. Parkhurst, B.M. Doube \& V.V.S.R. Gupta (eds.). Biological Indicators of Soil Health. CAB International, Oxon, UK.

Doi, R. 2005. Effects of air-drying soils on discriminating the soils with community-level physiological profiling. J. Gen. Appl. Microbiol. 51: 379-383.

Doi, R. \& K. Sakurai. 2004. Principal components derived from soil physico-chemical dataexplained a land degradation gradient, and suggested the applicability of new indexes for estimation of soil productivity in the Sakaerat Environmental Research Station, Thailand. Int. J. Sustain. Dev. World Ecol. 11: 298-311.

Doi, R. \& S.L. Ranamukhaarachchi. 2007a. Integrative evaluation of rehabilitative effects of Acacia auriculiformis on degraded soil. J. Trop. For. Sci. 19: 150-163.

Doi, R. \& S.L. Ranamukhaarachchi. 2007b. Soil colour designation using Adobe PhotoshopTM in estimating soil fertility restoration by Acacia auriculiformis plantation on degraded land. Curr. Sci. 92: 16041609.
Ehlers, W., O. Wendroth \& F. de Mol. 1995. Characterizing pore organization by soil physical parameters, p. 257-275. In K.H. Hartge \& B.A. Stewart (eds.). Soil structure: its development and function. CRC, Boca Raton, Florida, USA.

El-Keblawy, A. \& T. Ksiksi. 2005. Artificial forests as conservation sites for the native flora of the UAE. Forest Ecol. Manage. 213: 288-296.

FAO/UNESCO 1979. Soil map of the world. IX, Southeast Asia, UNESCO, Paris, France.

Gianfreda, L. \& J.M. Bollag. 1996. Influence of natural and anthropogenic factors on enzyme activity in soil, p 123-194. In G. Stotzky \& J.M. Bollag (eds.). Soil biochemistry, Vol 9. Dekker, New York, USA.

Handman, H., D.M. Weller \& L.S. Thomashow. 1991. Relative importance of fluorecent siderphores and other factors in biological control of Gaeumannomyces graminis var. tritici by Pseudomonas fluorecens 2-79 and M4-80R. Appl. Environ. Microbiol. 57: 32703277.

Heijnen, C.E., C. Chenu \& M. Robert. 1993. Micromorphological studies on clay-amended and unamended loamy sand, relating survival of introduced bacteria and soil structure. Geoderma, 56: 195-207.

Herman, D.C. \& R.M. Maier. 2000. Chapter 11. Physiological methods, p. 235-267. In R.M. Maier, I.L. Pepper \& C.P. Gerba (eds.). Environmental microbiology. Academic, San Diego, USA.

Hinojosa, M.B., J.A. Carreira, R. García-Ruíz \& R.P. Dick 2004. Soil moisture pre-treatment effects on enzyme activities as indicators of heavy metal-contaminated and reclaimed soils. Soil Biol. Biochem. 36: 15591568 .

Kaeoniam, P., P. Khoorat, W. Sunthornsan, M. Issareeya, C. Cherdchun \& W. Buachum. 1976. A study of illegal deforestation in the reserved forest area at the Sakaerat Environmental Research Station. Environmental and Ecological Research Department, Applied Scientific Research Corporation of Thailand, Bangkok, Thailand.

Kaiser, H.F. 1960. The application of electronic computers to factor analysis. Educ. Psych. Meas. 20: 141-151.

Kamo, K., T. Vacharangkura, S. Tiyanon, C. Viriyabuncha, S. Nimpila \& B. Doangsrisen. 2002. Plant Species Diversity in Tropical Planted Forests and Implication for Restoration of Forest Ecosystems in Sakaerat, Northeastern Thailand. JARQ 36: 111-118. 
Kanzaki, M., K. Yoda \& K. Dhanmanonda. 1995. Mosaic structure and tree growth pattern in a monodomoionant tropical seasonal evergreen forest in Thailand. p. 495-513. In E.O. Box, R.K. Peet, E. Masuzawa, I. Yamada, K. Fujiwara \& P.F. Maycosk (eds) Vegetation science in forestry. Kluwer, Netherlands.

Karr, D.B. \& D.W. Emerich. 2000. Bradyrhizobium japonicum isocitrate dehydrogenase exhibits calciumdependent hysteresis. Arch. Biochem. Biophys. 376: $101-108$.

Köppen, W. 1931. Grundriss der Klimakunde. Walter de Gruyter, Berlin, Germany.

Leij, F.J., T.A. Ghezzehei \& D. Or. 2002. Modeling the dynamics of the soil pore-size distribution. Soil Till. Res. 64: 61-78.

López-Gutiérrez, J.C., M. Toro \& D. López-Hernández. 2004. Seasonality of organic phosphorus mineralization in the of the native savanna grass, Trachypogon plumosus. Soil Biol. Biochem. 36: 1675-1684.

Lu, D., E. Moran \& P. Mausel. 2002. Linking Amazonian secondary succession forest growth to soil properties. Land Degrad. Dev. 13: 331-343.

McCune, J.B. Grace \& D.L.. Urban, 2002. Analysis of ecological communities. M \& M Softwre, Oregon, USA.

Moran, E.F., E.S. Brondizion, J.M. Tucker, M.C. da SilvaForsberg, S. McCracken \& I. Falesi. 2000. Effects of soil fertility and land-use on forest succession in Amazônia. For. Ecol. Manage. 139: 93-108.
Paul, E.A. \& F.E. Clark. 1989. Soil microbiology and biochemistry. Academic, San Diego, USA.

Rao, M.A., F. Sannino, G. Nocerino, E. Puglisi \& L. Gianfreda. 2003. Effect of air-drying treatment on enzymatic activities of soils affected by anthropogenic activities. Biol. Fertil. Soil 38: 327-332.

Ross, D.J. \& B.A. McNeilly. 1972. Effects of storage on oxygen uptakes and dehydrogenase activities of beech forest litter and soil. New Zealand J. Sci. 15: 453-462.

Smith, E.L., R.L. Hill, I.R. Lehman, R.J. Lefkowitz, P. Handler \& A. White. 1983. Principles of biochemistry: general aspects. McGrow-Hill, Singapore.

Soares, R.A., L.F.W. Roesch, G. Zanatta, F.A. Camargo \& L.M.P. Passaglia,. 2006. Occurrence and distribution of nitrogen fixing bacterial community associated with oat (Avena sativa) assessed by molecular and microbiological techniques. Appl. Soil Ecol. 33: 221-234.

Sollod, C.C., A.E. Jens \& M.E. Daub. 1992. Cell surface redox potential as a mechanism of defense against photosensitizers in fungi. Appl. Environ. Microbiol. 58: 444-449.

Wada, H., M. Saito \& Y. Takai. 1978. Effectiveness of tetrazolium salts in microbial ecological studies in submerged soil. Soil Sci. Plant Nutr. 24: 349-356.

Wingfield, G.I., H.A. Davies \& M.P. Greaves. 1977. The effect of soil treatment on the response of the soil microflora to the herbiside dalapon. J. Appl. Bacteriol. 43: 39-46. 